\title{
Perlindungan Hukum Terhadap Hak Pengelolaan Dan Pemanfaatan Atas Tanah Hak Adat Milik Niowula Yang Berada Dalam Area Taman Nasional Kelimutu
}

\author{
Johanes Pande \\ Fakultas Hukum Universitas Flores, Jln. Samratulangi Ende - Flores - NTT, \\ pandejohanes@gmail.com \\ Christiana Sri Murni, \\ Fakultas Hukum Universitas Flores, Jln. Samratulangi Ende - Flores - NTT, \\ srimurni.uniflor61@gmail.com \\ Bernadus B. Kelen \\ Fakultas Hukum Universitas Flores, Jln. Samratulangi Ende - Flores - NTT, \\ kelenbernadus@gmail.com
}

\begin{abstract}
ABSTRAK
Pengakuan dan perlindungan masyarakat adat telah tertera dalam berbagai peraturan perundang-undangan, namun secara implisit tidak mengatur bentuk hak-hak tradisional maupun unsur-unsur masyarakat adat. Eksistensi hak masyarakat adat Niowula Kabupaten Ende semakin tergerus oleh berbagai kebijakan pemerintah yang merampas eksistensi hak masyarakat adat disekitar Taman Nasional Kelimutu (TNK). akibat adanya penetapan zonasi khusus kawasan konservasi yang mengorbankan wilayah/lahan garapan (pertanian dan perkebunan kopi seluas kurang lebih $35 \mathrm{Ha}$ ) milik masyarakat hukum adat Desa Niowula Kecamatan Detusoko yang keberadaannya sudah lama sebelum adanya Taman Nasional Kelimutu. Pemerintah dalam hal ini Taman Nasional Kelimutu cenderung menggunakan dan menegakkan hukum negara dengan mengatasnamakan kepentingan pembangunan nasional, sedangkan di pihak lain masyarakat adat yang seharusnya menguasai dan berhak mengelola sumber daya alam di wilayah mereka sendiri sebagai mata pencaharian dan sumber perekonomian diabaikan.Permasalahan dalam penelitian ini adalah Peraturan hukum apa saja yang dapat dijadikan dasar masyarakat dalam mengelola kawasan konservasi (TNK) Kabupaten Ende. Metode yang digunakan dalam penelitian ini, adalah penelitian hukum normatif,dengan pendekatan "pendekatan ketatanegaraan" (statute approach).Hasil penelitian terjadi konflik antara Masyarakat adat Niowula Kabupaten Ende dengan (TNK) berkaitan dengan penetapan zonasi kawasan konservasi yang mengorbankan lahan garapan seluas kurang lebih $35 \mathrm{Ha}$ milik masyarakat adat Desa Niowula Kecamatan Detusoko. Sementara Putusan MK 35/PUUX/2012, telah merubah status dan kedudukan hukum hutan adat, dari yang awalnya "hutan adat adalah hutan negara menjadi "hutan adat adalah hutan yang berada dalam wilayah masyarakat hukum adat”. Putusan MK tersebut mengembalikan hak masyarakat adat untuk mengelolah hutan adatnya.
\end{abstract}

Kata Kunci: Perlindungan, Pengelolaan, Hak Masyarakat Adat. 


\begin{abstract}
Recognition and protection of indigenous peoples has been stated in various laws and regulations, but implicitly does not regulate the form of traditional rights or elements of indigenous peoples. The existence of the rights of the Niowula indigenous people in Ende Regency has been increasingly eroded by various government policies that have robbed the existence of the rights of indigenous peoples around the Kelimutu National Park (TNK). due to the establishment of special zoning for conservation areas at the expense of cultivated land (agriculture and coffee plantations covering an area of approximately 35 hectares) belonging to the customary law community of Niowula Village, Detusoko District, which existed long before the existence of Kelimutu National Park. The government, in this case the Kelimutu National Park, tends to use and enforce state laws in the name of the interests of national development, while on the other hand, indigenous peoples who are supposed to control and have the right to manage natural resources in their own territories as a source of livelihood and economic resources are neglected. The problem in this research is what legal regulations can be used as the basis for the community in managing the conservation area (TNK) of Ende Regency. The method used in this research is normative legal research, with a statute approach. The result of the research is that there is a conflict between the indigenous peoples of Niowula, Ende Regency and (TNK) regarding the zoning of a conservation area which has sacrificed an area of approximately 35 hectares of cultivated land belonging to the indigenous people of Niowula Village, Detusoko District. Meanwhile, the Constitutional Court Decision 35 / PUU-X / 2012, has changed the status and legal position of customary forests, from what was originally "customary forest is state forest to" customary forest is forest within the territory of customary law communities ". The Constitutional Court's decision restores the rights of indigenous peoples to manage their customary forests.
\end{abstract}

Keywords: Protection, Management, Rights of Indigenous Peoples. 


\section{Perlindungan Hukum Terhadap Hak Pengelolaan Dan Pemanfaatan Atas Tanah Hak Adat Milik Niowula Yang Berada Dalam Area Taman Nasional Kelimutu - Johanes Pande, Christiana Sri Murni \& Bernadus B. Kelen}

\section{PENDAHULUAN}

\section{A. Latar Belakang}

Perkembangan hukum di tanah air saat ini telah banyak menghasilkan pengaturan secara normatif terhadap Hak asasi manusia termasuk di dalamnya telah mengangkat eksistensi hak ulayat masyarakat adat. Penghormatan eksistensi hak ulayat masyarakat adat sebagai salah satu hak asasi manusia, (Pasal 6 ayat (1) serta identitas budaya dalam masyarakat tradisional (pasal 6 ayat (2). Undang-Undang Nomor 39 Tahun 1999 tentang HAM. ${ }^{1}$

Amanat Pasal tersebut diatas membuka ruang bagi masyarakat adat untuk dapat memanfaatkan hasil hutan dalam kawasan, sebagaimana dipertegas oleh Pasal 1 angka (18) Peraturan Pemerintah Nomor 6 Tahun 1999 tentang penguasaan hutan dan pemungutan hasil hutan produksi yang pada intinya menegaskan bahwa penguasaan dan pemanfaatan kawasan hutan diprioritaskan pada masyarakat setempat yang berdasarkan kekerabatan, kesamaan mata pencaharian, serta asal usulnya yang terikat dengan hutan. Komunitas yang dimaksud oleh Pasal 1 ayat $18^{2}$ tersebut dipertegas lagi dengan pasal 27 ayat $1^{3}$ yang mengisyaratkan bahwa komunitas tersebut sepanjang keberadaannya masih ada dan diakui di tempat tinggalnya.

Sedangkan menyangkut hak ulayat sebagaimana amanat Pasal 1 angka (1) Kepmen Agraria/KBPN Nomor 5 Tahun 1999 tentang Pedoman Penyelesaian Hak Ulayat Masyarakat Hukum Adat pada intinya menyatakan hak ulayat adalah wewenang yang dimiliki oleh masyarakat adat tertentu atas

\footnotetext{
${ }^{1}$ Pasal 6 Ayat (1) Undang-Undang Nomor 39 Tahun 1999 Tentang Hak Asasi Manusia “Dalam rangka penegakan hak asasi manusia perbedaan dan kebutuhan dalam masyarakat hukum adat harus diperhatikan dan dilindungi oleh hokum, masyarakat dan pemerintah".

Pasal 6 Ayat (2) Undang-Undang Nomor 39 Tahun 1999 Tentang Hak Asasi Manusia "Identitas budaya masyarakat hokum adat, termasuk hak atas tanah ulayat dilindungi, selaras dengan perkembangan zaman"

${ }^{2}$ Pasal 1 Ayat (18) PP Nomor 6 Tahun 1999 tentang penguasaan hutan dan pemungutan hasil hutan produksi Masyarakat setempat adalah kelompok-kelompok orang warga negar Republik Indonesia yang tinggal didalam atau sekitar hutan yang memiliki cirri sebagai suatu komunitas, yang didasarkan pada kekerabatan, kesamaan mata pencaharian yang berkait dengan hutan (profesi), kesejarahan, kerterikatan tempat tinggal bersama serta factor ikatan komunitas lainnya".

3 Pasal 27 ayat (1) PP Nomor 6 Tahun 1999 tentang penguasaan hutan dan pemungutan hasil hutan produksi Masyarakat hukum adat sepanjang menurut kenyataannya masih ada dan diakui keberadaannya berdasarkan Peraturan Pemerintah ini diberikan hak memunggut hasil hutan untuk memenuhi keperluan hidup sehari-hari".
} 
wilayah, yang muncul karenaadanya hubungan secara lahiriah dan batiniah secara turun temurun dengan wilayah yang bersangkutan.

Sebagaimana masalah yang berkenaan dengan hak masyarakat adat di Desa Niowula, Kecamatan Detusoko, Kabupaten Ende dalam mengelola dan memanfaatkan hak ulayatnya yang ada, telah mengusahakan sebagian hak ulayatnya dengan usaha pertanian dan perkebunan dengan menanam tanaman kopi sebagai bentuk usaha dalam meningkatkan taraf kehidupannya. Namun dalam perkembangannya dengan adanya penetapan zonasi Taman Nasional Kelimutu oleh instansi terkait (Taman Nasional Kelimutu dan lembaga Konservasi Sumber Daya Alam) berdasarkan regulasi yang ada, mengakibatkan pengelolaan kawasan hutan menjadi tertutup terhadap akses masyarakat adat sebagai pemilik lahan pertanian/perkebunan, sehingga sebagian tanaman produksi, dan potensi lainnya milik masyarakat adat yang telah menjadi kawasan hutan Taman Nasional Kelimutu tidak dapat dimanfaatkan lagi oleh masyarakat adat sebagai pemiliknya. Hal ini sangat merugikan masyarakat, sehingga masyarakat kehilangan mata pencaharian sebagai sumber pendapatan.

\section{B. Rumusan Masalah}

Peraturan hukum apa saja yang dapat dijadikan dasar masyarakat dalam mengelola kawasan hutan Taman Nasional Kelimutu di Kabupaten Ende.

\section{Metode Penelitian}

\section{Jenis Penelitian}

Jenis penelitian ini adalah penelitian hukum normatif. Menurut Soerjono Soekanto dan Sri Mamudji menyatakan bahwa penelitian hukum "normatif"yaitu penelitian berkitan dengan bahan pustaka merupakan data dasar yang dalam penelitian digolongkan sebagai data sekunder, yang mencakup penelitian terhadap buku-buku, dokumen resmi yang dikeluarkan pemerintah, asas-asas hukum, sistematika hukum, taraf sinkronisasi vertikal dan horisontal, perbandingan hukum, dan sejarah hukum. ${ }^{4}$

2. Pendekatan penelitian

Pendekatan yang digunakan dalam penelitian ini adalah "pendekatan

${ }^{4}$ Soerjono Soekanto dan Sri Mamudji, 2013, Penelitian Normatif Suatu Tinjauan Singkat, PT. Raja Garfindo Persada, Jakarta: hlm. 24 


\section{Perlindungan Hukum Terhadap Hak Pengelolaan Dan Pemanfaatan Atas Tanah Hak Adat Milik Niowula Yang Berada Dalam Area Taman Nasional Kelimutu - Johanes Pande, Christiana Sri Murni \& Bernadus B. Kelen}

ketatanegaraan" (statute approach), yang meliputi pendekatan perundangundangan, pendekatan sejarah hukum, pendekatan konsep, dan literatur yang berkaitan dengan kejelasan hukum tentang adanya ruang atau akses masyarakat dalam pengelolaan Hutan Hak dalam areal Taman Nasional Kelimutu.

3. Pengumpulan dan Analisis Bahan Hukum

Prosedur pengumpulan bahan hukum dilakukan dengan cara studi dokumen, yakni penelusuran dokumen-dokumen bahan hukum satu per satu dengan menggunakan kartu, kemudian dipelajari dengan saksama untuk menemukan bahan yang diperlukan sesuai dengan masalah penelitian. Data yang diperoleh kemudian dicatat dalam lembaran data dan diklasifikasikan menurut jenisnya. Sedangkan pembahasan/analisisdalam penelitian ini menggunakan metode deskriptif analitis.

\section{PEMBAHASAN}

Salah satu asas dibentuknya peraturan perundang-undangan adalah asas "lex superior derogate lex inferiori" yang artinya peraturan yang tingkatannya lebih rendah, tidak boleh bertentangan dengan peraturan yang lebih tinggi tingkatannya.Asas ini menegaskan bahwa peraturan yang lebih rendah tingkatannya, tidak mempunyai kekuatan hukum mengikat apabila isinya bertentangan dengan ketentuan peraturan yang lebih tinggi tingkatannya.

Dalam Konstitusi Negara Indonesia, kehadiran masyarakat adat beserta hakhak tradisionalnya diakui dan diatur dalam Pasal 18B ayat $(2)^{5}$, Selain mengakui masyarakat adat dan hak-hak tradisionalnya, Pasal 28I ayat (3) Undang-undang Dasar Negara Kesatuan Republik Indonesia Tahun 1945 juga menegaskan bahwa negara mengakui Hak Asasi Manusia (warga negara). Hal ini berarti konstitusi menghendaki adanya dua pendekatan dalam mengakui dan melindungi masyarakat adat; yaitu pendekatan fungsional yang meletakkan masyarakat adat sebagai pelaksana pemerintahan di tingkat yang paling kecil dan pendekatan HAM. yang mengharuskan

5 Pasal 18B ayat (2) Undang-Undang Dasar 1945 “Negara mengakui dan menghormati kesatuan-kesatuan masyarakat hokum adat beserta hak-hak tradisionalnya sepanjang masih hidup dan sesuai dengan perkembangan masyarakat dan prinsip Negara Kesatuan Republik Indonesia yang diatur dalam undangundang". 
negara mengambil peran strategis dalam pemenuhan, perlindungan dan pemajuan HAM (termasuk hak masyarakat adat). Namun kenyataannya berbagai regulasi yang ada seperti Undang-Undang Kehutanan, Undang-Undang Pemerintahan Daerah, Undang-Undang Perlindungan dan Pengelolaan Lingkungan Hidup, Undang-Undang Perkebunan dan sebagainya masih sangat dominan dengan pendekatan fungsional, dan sangat minim menggunakan pendekatan HAM. Perubahan pendekatan dari semula hanya pendekatan fungsional, kemudian di era reformasi diperluas dengan pendekatan Hak Asasi Manusia (HAM), yang berimplikasi pada perubahan hukum, khususnya berbagai peraturan-peraturan di bawah Undang-Undang Dasar berbenturan normanya terhadap konstitusi Negara (UUD 1945). Hal ini menuntut pemerintah untuk melakukan penyelarasan atau harmonisasi antara satu peraturan dengan peraturan lainnya.

Untuk lebih detail menyangkut kepemilikan, pengelolaan serta pemanfaatan hutan menurut regulasi yang ada, maka berikut ini peneliti akan menguraikan tentang Pengaturan hutan adat dalam versi peraturan-peraturan sebelum dan sesudah putusan MK.35.

\section{Pengakuan dan Perlindungan Terhadap Masyarakat Adat dan Hak-hak}

\section{Tradisionalnya}

Secara terminologis pengakuan berarti perbuatan mengaku atau mengakui. Sedangkan mengakui berarti menyatakan berhak. ${ }^{6}$ Sedangkan pengakuan melalui hukum Negara (hukum positif) diartikan sebagai hukum yang dibuat oleh orang atau lembaga-lembaga yang memiliki kewenangan, dan pengakuan tersebut diberlakukan terhadap anggota-anggota masyarakat yang merdeka. Anggota masyarakat tersebutpun mengakui kedaulatan/kekuasaan atau supremitas yang dimiliki orang atau lembagalembaga pembuat hukum yang besangkutan. Dengan demikian kebiasaan, menurutnya hanya akan berlaku sebagai hukum jika Undang-undang menghendaki atau menyatakan dengan tegas atas keberlakuan kebiasaan tersebut. ${ }^{7}$

Pengakuan tentang adanya hak masyarakat adat pertama kali dijumpai dalam UUPA yakni dalam pasal 3. Namun UUPA sendiri tidak memberikan definisi tentang masyarakat adat (masyarakat Hukum Adat versi UUPA). Selain itu istilah masyarakat

Suharso dan Anna Retnoningsih, Kamus Besar Bahasa Indonesia, Widya Karya, Semarang, 2014, hlm. 25. Otje Salman Soemadiningrat, Rekonseptualisasi Hukum Adat Kontemporer, PT. Alumni, Bandung, 2002, hlm. 2. 


\section{Perlindungan Hukum Terhadap Hak Pengelolaan Dan Pemanfaatan Atas Tanah Hak Adat Milik Niowula Yang Berada Dalam Area Taman Nasional Kelimutu - Johanes Pande, Christiana Sri Murni \& Bernadus B. Kelen}

hukum adat/masyarakat adat juga dijumpai dalam Pasal 1 ayat (3) Peraturan Menteri Agraria/Kepala Badan Pertanahan Nasional Nomor 5 Tahun 1999 tentang Pedoman Penyelesaian Masalah Hak Ulayat Masyarakat Hukum Adat.

Peraturan tersebut di atas seharusnya dapat dijadikan dasar hukum bagi pemangku adat/masyarakat adat untuk memperjuangkan haknya, apabila hak ulayat mereka diganggu, karena fakta menunjukan bahwa mereka memang sudah menempati dan menggarap tanah warisan leluhur dari generasi ke generasiyang telah berlangsung berabad-abad lamanya. Kehadiran UU Nomor 41 tahun 1999 tentang Kehutanan (selanjutnya di sebut UUK), menunjukkan bentuk keragu-raguan negara terhadap pengakuan eksistensi hutan adat. Jika dikaji dari beberapa pasalnya seperti antara lain Pasal 4 ayat (1,2 dan 3) UUK yang pada pokoknya mengklaim bahwa hutan di wilayah Republik Indonesia termasuk kekayaan alamnya dikuasai oleh Negara. Penguasaan Negara dimaksud memberikan hak kepada pemerintah dalam mengatur, mengurus dan menetapkan status hutan dan hubungan hukum antara orang dengan hutan serta mengatur perbuatan hukum terhadap hutan dengan memperhatikan hak masyarakat adat yang dalam kenyataannya masih ada dan diakui keberadaannya. Namun di Pasal 5 ayat (1) UUK, negara kembali melakukan penyangkalan terhadap keberadaan masyarakat adat dengan menetapkan hutan menurut statusnya hanya ada hutan Negara dan hutan hak. Di dalam Hutan negara, terdapat pula hutan adat.

Dari segi pengertian Hutan Negara merupakan hutan yang berada pada tanah yang tidak dibebani hak atas tanah, secara logika dapat dikatakan bahwa hutan adat tidak masuk dalam kategori hutan negara sebab, diatas wilayah hutan adat melekat hak atas tanah yang dimiliki oleh masyarakat adat yang secara geneologis telah lahir dan diwariskan secara turun temurun dari leluhur mereka yang dikenal dengan istilah hak ulayat. Oleh karena itu maka hutan adat bukan lahir dari hutan negara, Selama ini, kawasan hutan adat diklaim sebagai hutan negara. Padahal, seharusnya hutan negara tidak akan ada sepanjang hutan hak dan hutan adat belum ditetapkan.

Status hutan adat yang dikategorikan sebagai hutan negara menurut UUK, telah mengakibatkan masyarakat adat dirampashak-hak adatnyadari wilayah adatnya dan dikriminalisasi oleh pemerintah. Oleh karena itu, sebelum reformasi lahir berbagai bentuk perjuangan menuntut pengakuan hutan adat baik oleh masyarakat maupun LSM. Alhasil, melalui gerakan merevisi UUK, Mahkamah Konstitusi membuat suatu 
keputusan yang dengan mengeluarkan hutan adat dari hutan negara dan meletakannya menjadi bagian dari wilayah adat dan dimiliki oleh masyarakat adat.

Dengan demikian Pengakuan Hutan merupakan bagian dari hutan Negara, telah selama ini telah menimbulkan ketidakpastian kedudukan masyarakat adat beserta hak-hak tradisionalnya dalam kawasan hutan adat serta ketidakpastian hak pengelolaan hutan oleh masyarakat adat tersebut. Hal ini telah menuai konflik tenurial antara masyarakat hukum adat dengan Negara dan atau kelompok bisnis sebagai pihak ketiga dalam pemanfaatan dan pengelolaan sumber daya hutan, yang pada akhirnya menimbulkan kemerosotan perekonoman masyarakat adat yang berada disekitar kawasan hutan TNK karena tidak memiliki kewenangan untuk memanfaatkan dan mengelola hasil hutan yang sesungguhnya sebagai potensi untuk menghidupi dan mensejahterakan anggota keluarga maupun Komunitas adatnya.

Pengakuan dan perlindungan terhadap keberadaan masyarakat adat desa Niowula dan hak-hak tradisionalnya menjadi antara "ada" dan "tiada" atau "hidup" dan "mati" (ambiguitas). Karena secara harafiah pernyataan pengakuan dan perlindungan masyarakat hukum adat tertera dalam berbagai peraturan perundangundangan, namun secara implisit tidak mengatur bentuk hak-hak tradisional maupun unsur-unsur masyarakat hukum adat. Di samping itu tidak adanya kesatuan lembaga pemerintah pusat maupun daerah yang menangani masyarakat adat itu sendiri. Oleh karena itu, bentuk hak masyarakat adat dan unsur-unsur masyarakat adat selama ini ditetapkan sepihak secara sektoral oleh lembaga yang menangani sektor-sektor tertentu. Hal ini tentunya akan berakibat pada merebaknya konflik antara masyarakat adat dengan lembaga pemerintah. Karena bagi masyarakat adat, keberadaan tanah merupakan suatu hal yang esensial dan mempunyai hubungan yang holistic serta bermakna sebagai eksistensi diri, kohesi sosial, akar kultural dan aset ekonomi. Secara kultural tanah bagi masyarakat adat bermakna religio magis, yaitu pemberian Tuhan yang harus di pelihara dan di jaga sebaik-baiknya dan diwariskan secara turun temurun kepada genarasi berikutnya. Kepemilikan tanah bagi masyarakat adat dapat berupa lahan pertanian, perkebunan, padang penggembalaan, pemakaman, kolam, sungai dan hutan serta isinya.

Dengan adanya pengakuan terhadap eksistensi hukum adat tersebut diatas, maka secara hukum pemerintah telah memberikan hak kepada masyarakat adat yang 


\section{Perlindungan Hukum Terhadap Hak Pengelolaan Dan Pemanfaatan Atas Tanah Hak Adat Milik Niowula Yang Berada Dalam Area Taman Nasional Kelimutu - Johanes Pande, Christiana Sri Murni \& Bernadus B. Kelen}

diikuti dengan otoritas tertentu terhadap objek pengakuan, sehingga kemudian melahirkan kewenangan bagi subjek yang dilindungi oleh hukum positif. Dengan demikian maka perlindungan hak masyarakat adat dari perspektif hukum nasional mencakup pengakuan dan penghormatan masyarakat hukum adat. Pengakuan dan penghormatan tersebut merupakan pengesahan yang bersifat formal terhadap status tertentu sehingga berkorelasi dengan penghormatan.

Pada hakekatnya hukum adat bersifat komunalistis, dimana dimungkinkan adanya penguasaan tanah secara perorangan dan juga mengandung aspek kebersamaan. Komunalistis menunjukan eksistensi adanya hak bersama atas tanah yang lazim dalam hukum adat yang disebut hak ulayat masyarakat adat, sebagai hak tradisional yang harus di hormati dan diakui eksistensinya. ${ }^{8}$

Sebagaimana konflik yang terjadi di Kabupaten Ende oleh TNK akibat adanya penetapan zonasi khusus kawasan konservasi yang mengorbankan wilayah/lahan garapan (perkebunan kopi seluas kurang lebih $35 \mathrm{Ha}$ ) milik masyarakat adat Desa Niowula Kecamatan Detusoko yang keberadaannya sudah lama sebelum adanya TNK. Pemerintah dalam hal ini TNK cenderung menggunakan dan menegakkan hukum Negara dengan mengatasnamakan kepentingan pembangunan nasional, sedangkan di pihak lain masyarakat adat yang awalnya menguasai dan mengelola potensi sumber daya alam di wilayah mereka sendiri sebagai mata pencaharian dan sumber perekonomian diabaikan. Konflik vertical ini melahirkan pandangan dalam masyarakat adat bahwa pemerintah telah melakukan perampasan terhadap tanah yang merupakan hak miliknya, sedangkan disatu sisi pemerintah memandang masyarakat baik secara perserorangan maupun secara bersama dalam kolektivitas masyarakat adat telah bertindak sebagai perambah dan mengambil, atau menebang kayu dalam hutan atau areal hutan lindung yang telah ditetapkan oleh pemerintah. Konflik ini dalam dunia kehutanan di kenal dengan konflik land tenure.

Adapun sejarah lahirnya dasar hukum Penunjukan Dan Penetapan Batas Kawasan Taman Nasional Kelimutu, yakni berawal dari SK Gubernur Nusa Tenggara Timur No.45/BKLH/Tahun 1982 tanggal 30 Maret 1982 yakni menunju kKawasan Hutan Sokoria seluas \pm 5.000 Hayang terletakdi Kabupaten Endese bagaihutan wisata

\footnotetext{
${ }^{8}$ Lilik Mulyadi, eksistensi, dinamika dan perlindungan hokum terhadap hak atas tanah ulayat masyarakat adat di Indonesia, 2017, PT. Alumni, Bandung, hlm. 62.
} 
yang diberinama Taman Wisata Kelimutu; kemudian disusul dengan Keputusan Menteri Kehutanan No.89/Kpts-II/1983 tanggal 2 Desember 1983 yang menunjukarealhutandiPropinsiNusa Tenggara Timurseluas $\pm 1.667 .962 \mathrm{Ha}$ sebagaikawasan hutan tetap,yang diantaranya terletakdi KelompokHutanSokoria (RTK.52) PulauFlores,y ang telahdilakukanpemancanganbatashutanpadaBulan Desember1983 s/d Januari1984 (Berita Acara Pengumuman Pemancangan Batas HutandariKelompok Hutan Sokoria (RTK.52) tanggal 1Februari1984. Berdasarkan Pengumuman Bataster sebut di sebabkan karenati dakadanya klaimdar imasyarakat ataspen gumuman tersebut.

Selanjutnya Menteri Kehutanan melalui Sura tKeputusanNo.185/Kpts-II/1984 tanggal 4 Oktober 1984 menunjuk Danau Kelimutu dan Hutan di sekitarnya seluas \pm 5.000 Hayangter letak di Daerah Tingkat II Ende Daerah Tingkat I Nusa Tenggara Timur sebagai Hutan Suaka Alamcq Cagar Alamseluas \pm 16 Ha,dansebagai HutanWisatacq Taman Wisataseluas $\pm 4.984 \mathrm{Ha}$. Padatanggal 6 Maret 1985, Menteri Kehutanankemudian mengesahkan Berita Acara Tata Batas yang diusulkan oleh pemerintah daerah kabupaten Ende pada waktu itu.

Kemudian Keputusan Menteri Kehutanan No.279/Kpts-II/1992 yang diterbitkan padatanggal 26 Februari 1992 merubah fungsi dan menunjuk Cagar Alam Danau Kelimutu dan Taman Wisata Kelimutudi Kabupaten Dati II Ende, Propinsi Daerah TingkatI Nusa Tenggara Timur seluas $\pm 5.000 \mathrm{Ha}$ menjadi Taman Nasional dengan nama "Taman Nasional Kelimutu ". Penetapan pengukuhan kawasan Taman Nasional Kelimutu sesuai hasil tatab atas tahun 1984seluas5.356,5Ha berdasarkan Keputusan Menteri KehutananNp.679/Kpts-II/1997 tanggal 10 Oktober 1997; Keputusan DirjenPHKANo.SK.69/IV-Set/HO/2006 tanggal 3 Mei 2006 tentang Penunjukan 20 (duapuluh) Taman Nasional sebagai Taman Nasional Model.

Terakhir Pengelolaan Taman Nasional Kelimutu ditetapkan berdasarkan Keputusan Menteri Kehutanan No.P.03/Menhut-II/2007 Tanggal 1 Pebruari2007 tentang Organisasi dan Tata Kerja Unit Pelaksana Teknis Taman Nasional, dalam pelaksanaannya Kawasan Taman Nasional Kelimutu di bagi dalam 2 (dua) Seksi Pengelolaan Taman Nasional Wilayah yaitu Seksi Pengelolaan Taman Nasional Wilayah I di Monidan Seksi Pengelolaan Taman Nasional Wilayah II diDetusoko.

Sebagaimana hasil penelitian tim peneliti bahwa luas Taman Nasional 


\section{Perlindungan Hukum Terhadap Hak Pengelolaan Dan Pemanfaatan Atas Tanah Hak Adat Milik Niowula Yang Berada Dalam Area Taman Nasional Kelimutu - Johanes Pande, Christiana Sri Murni \& Bernadus B. Kelen}

Kelimitu sebesar 5.356,5 Ha, berasal dari pengambilan lahan milik masyarakat adat yang berada disekitar Taman Nasional dengan rincian sebagai berikut:

\section{KONDISI PENUTUPAN LAHAN}

KAWASAN TAMAN NASIONAL KELIMUTU

\begin{tabular}{|c|l|r|r|r|r|r|r|}
\hline No. & $\begin{array}{c}\text { Penutupan } \\
\text { Lahan }\end{array}$ & $\begin{array}{c}\text { Luas } \\
\text { Wil.TN } \\
\text { Kelimutu }\end{array}$ & $\begin{array}{c}\text { Kec. } \\
\text { Wolojita }\end{array}$ & $\begin{array}{c}\text { Kec. } \\
\text { Ndona } \\
\text { Timur }\end{array}$ & $\begin{array}{r}\text { Kec. } \\
\text { Detusoko }\end{array}$ & $\begin{array}{c}\text { Kec. } \\
\text { Ndona }\end{array}$ & $\begin{array}{c}\text { Jumlah } \\
\text { Ha }\end{array}$ \\
\hline 1 & HutanPrimer & 498,75 & 443,06 & 262,50 & 778,37 & 647,81 & $2.630,49$ \\
\hline 2 & $\begin{array}{l}\text { HutanSekund } \\
\text { er }\end{array}$ & 216,25 & 19,09 & - & 193,75 & 86,80 & 515,89 \\
\hline 3 & $\begin{array}{l}\text { Semak } \\
\text { Belukar }\end{array}$ & 492,50 & 97,18 & 269,63 & 212,50 & 573,06 & $1.644,87$ \\
\hline 4 & $\begin{array}{l}\text { Padang } \\
\text { Rumput }\end{array}$ & 64,38 & - & 37,50 & 87,50 & 188,83 & 378,21 \\
\hline 5 & $\begin{array}{l}\text { Pasir/Daerah } \\
\text { Berbatu }\end{array}$ & 35,53 & 0,34 & 12,50 & 9,13 & 23,75 & 81,25 \\
\hline 6 & $\begin{array}{l}\text { Kawah/ } \\
\text { danau) }\end{array}$ & 105,10 & - & - & - & - & 105,10 \\
\hline 7 & HutanBambu & - & 0,70 & - & - & - & 0,70 \\
\hline 8 & $\begin{array}{l}\text { DaerahRawan } \\
\text { Kebakaran }\end{array}$ & 168,75 & 0,35 & 65,63 & 40,63 & 91,75 & 367,10 \\
\cline { 2 - 8 } & \begin{tabular}{l} 
LUAS(Ha) \\
\hline
\end{tabular} & $\mathbf{1 . 4 1 2 , 5 0}$ & $\mathbf{5 6 0 , 3 7}$ & $\mathbf{5 8 2 , 1 3}$ & $\mathbf{1 . 2 8 1 , 2 5}$ & $\mathbf{1 . 5 2 0 , 2 5}$ & $\mathbf{5 . 3 5 6 , 5 0}$ \\
\hline
\end{tabular}

Data tersebut diatas, menunjukan bahwa luas arealTNK sebesar 5.356,50 Ha, seluruhnya berasal dari hutan milik masyarakat adat yang berasal dari empat kecamatan di sekitar TNK. Saat penutupan lahan oleh Pemerintah menjadi arealTNK berdasarkan KeputusanMenteri KehutananNp.679/Kpts-II/1997 tanggal10 Oktober 1997, yang sesungguhnya sebagian lahan tersebut merupakan lahan garapan masyarakat adat berupa lahan pertanian dan perkebunan dengan jenis tanaman yang sudah ada seperti kopi, coklat, kemiri bahkan pemukiman/perumahan warga.

Beranjak dari konflik kepentingan antara pemerintah dalam hal ini Balai TNK dengan masyarakat adat, maka Pemerintah akhirya menyadari konflik land tenurial harus ditangani dengan hati-hati dengan mengedepankan aspek budaya, pendidikan, kesejahteraan dan keadilan masyarakat serta memperhatikan kepentingan umum/nasional. Hal ini mendorong pemerintah mengubah garis kebijakan yang 
dulunya berpihak kepada kekuasaan negara, menjadilebih berpihak kepada kesejahteraan masyarakat sekitar areal TNK, dengan memperhatikan arah pembangunan nasional.

Direvisinya PP 34 Tahun 2002 menjadi PP Nomor 6 tahun 2007 Tentang Tata Hutan dan Penyusunan Rencana Pengelolaan Hutan, serta Pemanfaatan Hutan dimana pemerintah mulai membuka ruang hak akses masyarakat dalam pengelolaan sumber daya hutan. Namun sangat disayangkan karena keberpihakan PP Nomor 6 tahun 2007 masih terbatas pada masyarakat yang punya kemampuan modal untuk ditanamkan pada bidang pengusahaan hutan di bandingkan dengan masyarakat yang membutuhkan sumber daya hutan untuk kebutuhan hidup dan perlengkapan rumah tangga. Walaupun ada hal yang menggembirakan dari PP nomor 6 tahun 2007 adalah ketetapan jumlah maksimum pemungutan hasil hutan kayu sebesar $20 \mathrm{~m} 3$ per keluarga untuk bahan bangunan dan tidak boleh diperjualbelikan.

\section{Pengelolaan dan Pemanfaatan Hak Ulayat Masyarakat Adat}

Dalam kamus umum Bahasa Indonesia memberikan pengertian pengelolaan sebagai berikut: ${ }^{9}$ “(1) Proses atau Cara atau Perbuatan mengelola, (2) Proses melakukan perbuatan tertentu dengan menggerakkan tenaga orang lain, (3) Proses yang membantu merumuskan kebijaksanaan dan tujuan organisasi, dan (4) Proses yang memberikan pengawasan pada semua hal yang terlibat dalam pelaksanaan kebijaksanaan dan pencapaian tujuan".

Pengelolaan diartikan sebagai sesuatu rangkaian pekerjaan atau usaha yang dilakukan oleh sekelompok orang untuk melakukan serangkaian kerja dalam mencapai tujan tertentu. Dikatakan manajemen adalah suatu proses perencanaan dan pengambilan keputusan, pengorganisasian, memimpin dan pengendalian organisasi manusia, keuangan, fisik dan informasi sumber daya guna mencapai tujuan organisasi. Proses manajemen melibatkan fungsi-fungsi yang ditampilkan oleh seorang manajer atau Pimpinan. Pengertian pengelolaan sebagai proses sebagai berikut: ${ }^{10}$

\footnotetext{
${ }^{9}$ Wilfridus Josephus Sabarija Poerwadarminta, Badan Pengembangan dan Pembinaan Bahasa, 2008, Kamus Besar Bahasa Indonesia edisi keempat tahun, Balai Pustaka, Jakarta.

${ }^{10}$ Nanang Fattah, 2004, http://eprints. uny. ac. id/7900/3/bab2\%20-\%2006101244019. pdf, hlm. 1
} 


\section{Perlindungan Hukum Terhadap Hak Pengelolaan Dan Pemanfaatan Atas Tanah Hak Adat Milik Niowula Yang Berada Dalam Area Taman Nasional Kelimutu - Johanes Pande, Christiana Sri Murni \& Bernadus B. Kelen}

1. Perencanaan (Planning) Perencanaan adalah suatu pemeliharaan yang berhubungan dengan waktu yang akandatang dalam menggambarkan dan merumuskan kegiatan-kegiatan yang diusulkan demi mencapai hasil yang dikehendaki.

2. Pengorganisasian (Organizing) Pengorganisasian adalah penentuan, pengelompokan, dan pengaturan berbagai kegiatan yang dianggap perlu untuk mencapai tujuan.

3. Pelaksanaan (Actuating) Pelaksanaan adalah usaha agar setiap anggota kelompok mengusahakan pencapaian tujuan dengan berpedoman pada perencanaan dan usaha pengorganisasian.

4. Pengawasan (Controlling)

Pengawasan adalah proses penentuan apa yang seharusnya diselesaikan yaitu penilaian pelaksanaan, bila perlu melakukan tindakan korektif agar pelaksanaannya tetap sesuai dengan rencana.

Menurut Pasal 1 ayat (4) Peraturan Pemerintah No. 24 tahun 1997 tentang Pendaftaran Tanah, bahwa hak pengelolaan adalah hak menguasai dari Negara yang kewenangan pelaksanaannya sebagian dilimpahkan kepada pemegangnya.

Perubahan UUD 1945, membawa perubahan model pendekatan konstitusional yang pada awalnya hanya mengenal model pendekatan fungsional menjadi dua model pendekatan yaitu pendekatan fungsional dan pendekatan HAM. Pendekatan fungsional berimplikasi pada adanya keharusan untuk meletakkan masyarakat adat sebagai pelaksana pemerintahan di tingkat yang paling kecil/bawah. Sementara pendekatan HAM mewajibkan negara mengambil peran strategis dalam pemenuhan, perlindungan dan pemajuan HAM (termasuk hak masyarakat adat). Namun berbagai regulasi yang ada seperti UU Kehutanan, UU Pemerintahan Daerah, UU Perlindungan dan Pengelolaan Lingkungan Hidup, UU Perkebunan dan sebagainya masih sangat dominan dengan pendekatan fungsional. Oleh karena itu setelah adanya amandemen UUD 1945 (mulai tahun 2002) sudah seharusnya dilakukan perubahan/penyesuaian peraturanperaturan yang tingkatannya lebih rendah dari UUD 1945. Misalnya di bidang kehutanan yang seharusnya sudah melakukan perubahan berdasarkan amanat Pasal 18B ayat (2) UUD 1945 yang merupakan bagian dari Bab Pemerintahan Daerah atau dengan istilah lain "masyarakat tradisional", Pasal 28I ayat (3) yang merupakan bagian dari Bab tentang Hak Asasi Manusia, Pasal 32 ayat (1) dan ayat (2). Pasal-pasal tersebut menunjukan bahwa konstitusi menghendaki adanya pelaksanaan 2 (dua) pendekatan sekaligus dalammemberi perlindungan hak-hak masyarakat adat; yaitu pendekatan secara fungsional dan pendekatan HAM. Pendekatan fungsional berimplikasi pada 
adanya keharusan untuk meletakkan masyarakat adat sebagai pelaksana pemerintahan di tingkat yang paling kecil. Sementara pendekatan HAM berarti negara mengambil peran strategis dalam pemenuhan, perlindungan dan pemajuan HAM (termasuk hak masyarakat hukum adat).

Sebagai garda konstitusi dalam Negara Kesatuan Republik Indonesia, MK telah secara tegas mengatakan bahwa selama ini Undang-undang Kehutanan Tahun 1999, telah salah secara konstitusional dengan memasukan kategori "hutan adat" ke dalam golongan "hutan negara" (hutan yang dimiliki oleh negara). Kategorisasi itu yang di praktikan oleh lembaga-lembaga pemerintah selama ini telah terindikasi bertentangan dengan UUD 1945 yakni Pasal 18B.

Menurut Putusan MK 35: "ketentuan Pasal 18B telah menempatkan satu hal yang sangat penting dan fundamental dalam lalulintas hubungan hukum yakni masyarakat adat secara konstitusional telah diakui dan di hormati sebagai subyek hukum/penyandang hak sehingga kepadanya dapat pula dibebani kewajiban. Sebagai subjek hukum di dalam suatu negara maka masyarakat adat haruslah mendapat perhatian sebagaimana subjek hukum lain dalam lalulintas hubungan hukum, terutama dalam rangka mengatur pengalokasian sumber-sumber kehidupan". Karena pada dasarnya dipandang bahwa: (1). Dalam lalulintas hubungan hukum terdapat subjek yang disebut masyaraat hukum adat, (2). Masyarakat hukum adat adalah penyandang hak, (3). Masyarakat adat adalah subjek hukum tersendiri, dan (4). Masyarakat adat adalah pemilik wilayah adatnya.

Setelah adanya putusan MK tersebut, diharapkan Pemerintah Daerah menjadi ujung tombak penting untuk mengimplementasikan Putusan MK 35. Namun masih banyak pemerintah daerah yang masih ragu terhadap kewenangan ini, karena sejumlah peraturan daerah yang lahir setelah putusan MK, umumnya masih bersifat pengaturan dan bukan penetapan terhadap Masyarakat Adat dan wilayahnya. Padahal Pemerintah Daerah dan Peraturan Daerah memegang peranan penting sebagai eksekutor Putusan MK 35 ini. Putusan MK 35 merupakan putusan sangat penting disebabkan menyangkut dua isu konstitusional yakni, pertama mengenai hutan adat dan yang kedua mengenai pengakuan bersyarat terhadap keberadaan masyarakat adat. Terdapat dua pikiran pokok dalam Putusan MK 35 tersebut yakni antara lain: 


\section{Perlindungan Hukum Terhadap Hak Pengelolaan Dan Pemanfaatan Atas Tanah Hak Adat Milik Niowula Yang Berada Dalam Area Taman Nasional Kelimutu - Johanes Pande, Christiana Sri Murni \& Bernadus B. Kelen}

Pertama: pernyataan Mahkamah Konstitusi bahwa Undang-undang Kehutanan menempatkan hutan adat sebagai bagian dari hutan negara merupakan bentuk pengabaian terhadap hak-hak masyarakat adat".Kedua: pernyataan untuk memulihkan hak-hak masyarakat adat yang selama ini "dirampas" atau "diabaikan".

Dikeluarkannya posisi Hutan adat dari sebelumnya sebagai bagian dari hutan Negara membawa konsekuensi harus ada perubahan Pasal 1 angka 6 Undang-undang Nomor 41 Tahun 1999 tentang Kehutananyang sebelum putusan MK 35: berbunyi "Hutan Adat adalah hutan Negara yang berada dalam wilayah masyarakat hukum Adat" dengan setelah putusan MK 35yakni bahwa posisi hutan adat merupakan bagian dari tanah ulayat masyarakat hukum adat.

Menanggapi amar putusan MK 35 tersebut, pemerintah harus mengakui keberadaan hutan adat yang ditempati oleh masyarakat adat dengan dikeluarkannya 3 peraturan teknis, yakni Peraturan Menteri Dalam Negeri (Permendagri) Nomor 52 Tahun 2014, Peraturan Menteri Lingkungan Hidup dan Kehutanan (Permenlhk) Nomor 32 Tahun 2015, dan Permenlhk Nomor 83 Tahun 2016. Namun, Peraturan Menteri tersebut masih memerlukan kebijakan lanjutan oleh pemerintah secara komprehensif dan konkrit agartidak berpotensi menimbulkan konflik baru bagi masyarakat adat.

Oleh karena itu, pemerintah perlu membuat roadmap kemana arah pengakuan hutan adat dan berada dibawah kewenangan kementerian yang mana. Hal ini bertujuan agar tidak terjadi tumpang tindih kewenangan antar kementerian sehingga akan menimbulkan masalah baru dalam harmonisasi kebijakan antara pusat dan daerah.. Selain itu, juga bertujuan untuk mencegah terjadinya saling lempar tanggunjawab nantinya jika terjadi pelanggaran atau penyimpangan dalam praktik.

Putusan MK 35 dan Peraturan lanjutannya hanya baru sebatas pengakuan yuridisnya saja, belum mengatur sampai pada tahap pemberdayaan hutan adat oleh masyarakat adat itu sendiri. Oleh karena itu Pemerintah perlu merumuskan kebijakan untuk menetapkan cara dan teknik pemberdayaan dalam pengelolaan hutan adat oleh masyarakat adat setempat yang berbasiskan kearifan lokalnya, baik bagi masyarakat adat yang sudah mandiri dan memiliki model pengusahaan hutan sendiri ataupun bagi masyarakat adat yang belum memiliki model pengusahaan hutan sendiri. Pentingnya dibuatkan model pemberdayaan ini, selain untuk meningkatkan kesejahteraan 
masyarakat adat, juga untuk melestarikan nilai-nilai yang hidup pada masyarakat adat sesuai dengan perkembangan zaman.

Dalam putusannya, MK telah membatalkan sejumlah kata, frasa dan ayat dalam UUK itu. Dalam hal ini MK memberi penafsiran bersyarat terhadap Pasal 5 ayat (1) UUKyakni sepanjang tidak dimaknai "Hutan Negara sebagaimana dimaksud pada ayat (1) huruf a, tidak termasuk hutan Adat"dan menghapus frasa dan pada ayat (2)" Pasal 5, yang mengatakan bahwa "Pasal 4 ayat (3) UUK bertentangan UUD 1945 tidak mempunyai kekuatan hukum mengikat sepanjang tidak dimaknai "penguasaan hutan oleh negara tetap memperhatikan hak masyarakat hukum adat, sepanjang masih hidup dan sesuai dengan perkembangan masyarakat dan prinsip NKRI". Di sini MK menekankan bahwa "harus ada pembedaan perlakuan terhadap hutan Negara dan hutan Adat", sehingga dibutuhkan pembaharuan pengaturan hubungan antara hak menguasai negara dengan hutan negara, dan hak menguasai negara terhadap hutan adat. Terhadap hutan negara, negara mempunyai wewenang penuh untuk mengatur tentang peruntukan, pemanfaatan, dan hubungan-hubungan hukum yang terjadi di dalam wilayah hutan negara, sedangkan terhadap hutan adat, wewenang negara dibatasi karena Hutan adat berada dalam cakupan hak ulayat dalam satu kesatuan wilayah (ketunggalan wilayah) masyarakat adat.

Masyarakat hukum adat mempunyai hak mengelolah hutan adatnya untuk dikuasai dan/atau diusahakan tanahnya bagi pemenuhan kebutuhan keluarga/komunitas adatnya. Jadi, tidak mungkin hak warga masyarakat adat tersebut ditiadakan atau dibekukan sepanjang keberadan masyarakat adat masih memenuhi syarat dalam cakupan pengertian kesatuan masyarakat adat sebagaimana amanat UUD 1945,karena menurut UUD 1945 hutan adat telah disejajarkan dengan hutan hak yang bersifat kolektif. Oleh karena itu maka tidak dimungkinkan hutan hak berada dalam wilayah hutan negara. Atau sebaliknya, seperti dinyatakan Pasal 5 ayat (2) UUK. Dengan putusan MK ini masyarakat hukum adat dapat kembali memperoleh haknya yang dijamin konstitusi. Namun demikian bukan berarti masyarakat adatdapat secara langsung berhak mengelola hutan adatnya, melinkan perlu adanya pengaturan secara yuridis dari pemerintah sebagai tindak lanjut dari putusan MK 35, sebab jika tanpa adanya pengaturan secara yuridis tentang masyarakat adat, maka status hutan masih 


\section{Perlindungan Hukum Terhadap Hak Pengelolaan Dan Pemanfaatan Atas Tanah Hak Adat Milik Niowula Yang Berada Dalam Area Taman Nasional Kelimutu - Johanes Pande, Christiana Sri Murni \& Bernadus B. Kelen}

belum bisa diketahui, yang mana hutan adat dan mana yang bukan. Hal ini bertujuan untuk mencegah adanya konflik baru yang dimanfaatkan pihak lain.

Menanggapi amar putusan MK tersebut, pemerintah telah mengeluarkan peraturan untuk mengakui keberadaan hutan adat yang ditempati oleh masyarakat adat dengan yakni: Permendagri Nomor 52 Tahun 2014 Tentang Penanganan Konflik Tenurial;Permenlhk Nomor 32 Tahun 2015 Tentang Hutan Sosial;danPermenlhk Nomor 83 Tahun 2016 Tentang Hutan Hak, yang pada intinya mengatur antara lain negara mempunyai wewenang penuh untuk mengatur peruntukan, pemanfaatan, dan hubungan-hubungan hukum yang terjadi di wilayah hutan negara,sedangkan terhadap hutan adat, wewenang negara dibatasi karenahutan adat berada dalam cakupan hak ulayat dalam satu kesatuan wilayah (ketunggalan wilayah) masyarakat adat. Oleh karena itu yang berwenang mengatur pemanfaatan dan pengelolaannya adalah masyarakat adat.

Disamping peraturan daerah yang akan mengukuhkan hutan adat (hutan ulayat)/hutan adat, juga sangat dibutuhkan tindakan pasrtisipasi masyarakat pemilik hak ulayat/hutan adat untuk melakukan tindakan nyata serta bekerja sama dengan pemerintah daerah guna melakukan verifikasi hutan ulayat/tanah ulayat milik masyarakat adat yang masih hidup dan kenyataannya masih hidup dan diakui oleh warga masyarakat adatnya yang terdiri dari letak, luas, batas-batas, bukti hak dan peta lokasi hutan adat yang menjadi hak masyarakat adat.

Menyadari akan masih jauhnya harapan masyarakat adat untuk mendapatkan hak atas hutan ulayat/tanah ulayat dari kawasan Taman Nasional Kelimutu, maka pemerintah telah memberikan ruang dalam pemanfaatan dan pengelolaan areal hutan dalam pengawasan pemerintah,sebagiamana amanat dalam Permenlhk Nomor P.84/Menlhk-Setjen/2015 tentang Penanganan Konflik Tenurial Kawasan Hutan yang pada pokoknya mengatur pemanfaatan hutan kawasan secara kemitraan antara masyarakat adat dan pemerintah sebagai bentuk kerjasama pemberdayaan masayarakat di kawasan konservasi. Hal ini di desa Niowula sudah dimulai dengan adanya kesepakatan kerjasama antara Taman Nasional Kelimutu bersama masayarakat Niowula yang memiliki perkebunan dalam kawasan konservasi Taman Nasional Kelimutu.

Peraturan Menteri Lingkungan Hidup dan Kehutanan Republik Indonesia Nomor P.84/Menlhk-Setjen/2015 tentang Penanganan Konflik Tenurial yang bertujuan 
untuk mengatur penanganan, penyelesaian, pengawasan terhadap pelaksanaan penyelesaian konflik tenurial kawasan hutan. Peraturan ini lahir dari kenyataan bahwa selama ini telah terjadi konflik tentang kepemilikan, pemanfaatan dan pengelolaan hutan yang masih memiliki masyarakat adat (seperti Daerah Kalimantan, Irian Jaya, NTT, NTB, Daerah Batak dan lain-lain).

Sedangkan berdasarkan Peraturan Presiden Nomor 88 Tahun 2017 Tentang Penyelesaian Penguasaan Tanah Dalam Kawasan Hutan sebagaimana realita yang terjadi di kawasan Taman Nasional Kelimutu, ada baiknya pola penyelesaian penguasaan tanah yang jika penguasaan hak atas hutan tersebut telah dikuasai dan/atau telah diberikan hak di atasnya sebelum bidang tanah/hutan tersebut ditunjuk sebagai kawasan hutan, maka penyelesaian dilakukan dengan mengembalikan bidang tanah/hutan tersebut dari kawasan hutan negara melalui perubahan batas kawasan hutan negara.

Walaupun telah ada Peraturan Presiden Nomor 88 Tahun 2017 tersebut diatas, namun pada bulan Juni tahun 2018 Menteri Lingkungan Hidup dan Kehutanan menerbitkan Peraturan Nomor P.6/KSDAE/SET/Kum.1/6/2018 Tentang Petunjuk Teknis Kemitraan Konservasi Pada Suaka Alam dan Kawasan Pelestarian Alam, yang memberikan ruang akses bagi masyarakat umumnya dan khususnya masyarakat desa Niowula yang berada disekitar kawasan Taman Nasional Kelimutu untuk memungut hasil hutan bukan kayu dengan batasan waktu, luas, alat dan/atau volume tertentu. (Pasal 1 ayat 19), Budidaya tradisional terbatas khusus untuk tanaman obat, tanaman untuk kebutuhan sehari-hari, satwa liar yang tidak dilindungi di zona/block tradisional dengan teknik sederhana yang sudah dikenal atau dipraktekkan secara turun temurun atau menurut kearifan lokal. (Pasal 1 ayat 20), Perburuan tradisional terbatas untuk menangkap satwa liar yang tidak dilindungi di zona/block tradisional dengan teknik sederhana yang sudah dikenal atau dipraktekkan secara turun temurun atau menurut kearifan lokal. (Pasal 1 ayat 21).

Adapun ruang lingkup kemitraan sesuai Peraturan dari Kementrian Lingkungan Hidup dan Kehutanan Direktorat Jenderal Konservasi Sumber Daya Alam dan Ekosistim Nomor P.6/KSDAE/SET/Kum.1/6/2018 Tentang Petunjuk Teknis Kemitraan Konservasi pada Suaka Alam dan Kawasan Pelestarian Alam meliputi pemberdayaan masyarakat, pemulihan ekosistem dan pembinaan, pengendalian monitoring dan 


\section{Perlindungan Hukum Terhadap Hak Pengelolaan Dan Pemanfaatan Atas Tanah Hak Adat Milik Niowula Yang Berada Dalam Area Taman Nasional Kelimutu - Johanes Pande, Christiana Sri Murni \& Bernadus B. Kelen}

evaluasi. Bentuk kemitraan dalam rangka pemberdayaan masyarakat setempat berupa pemberian akses pemungutan hasil hutan bukan kayu, budidaya tradisional, perburuan tradisional untuk jenis yang tidak dilindungi, serta wisata alam terbatas (Pasal 4 ayat (1) huruf a dan ayat (2).

Jenis-jenis Hasil Hutan Bukan Kayu (HHBK) sebagaimana dimaksud pada pasal 4 ayat (2) terdiri dari: kelompok rotan; kelompok getah; kelompok damar; kelompok biji-bijian; kelompok bunga-bungaan; kelompok daun-daunan; kelompok akar-akaran; kulit kayu; bambu hutan; buah-buahan; umbi-umbian; nibung; lilin tawon; madu; sagu; nipah; ijuk; tumbuhan obat dan jamur.

Dalam rangka pengakuan kesatuan-kesatuan masyarakat adat serta hak-hak tradisional di Kabupaten Ende telah ditetapkan Peraturan Daerah Nomor 2 Tahun 2017 tentang Penyelenggaraan Pengakuan Dan Perlindungan Masyarakat Hukum adat Di Kabupaten Ende.

Pengakuan merupakan pernyataan tertulis dan/atau lisan atas keberadaan masyarakat adat beserta hak-hak tradisionalnya oleh negara. Sedangkan perlindungan adalah bentuk pelayanan yang diberikan oleh negara kepada masyarakat adat. Pasal 6 Perda tersebut menyatakan masyarakat adat berhak atas tanah, wilayah, sumber daya alam, pembangunan, spiritual dan kebudayaan, lingkungan hidup, menjalankan hukum dan peradilan adat. Sedangkan Pasal 7 menyatakan bahwa masyarakat adat berhak atas tanah, wilayah adat, serta memanfaatkan segala potensi sumber daya alam yang ada di wilayah adatnya dengan tetap menjaga kelestariannya sepanjang tidak bertentangan dengan ketentuan peraturan perundang-undangan yang berlaku. Berdasarkan Peraturan Daerah Kabupaten Ende tersebut masyarakat adat telah diberikan hak untuk dapat mengakses sumber daya alam di dalam wilayah adatnya. Namun untuk dapat mengakses sepenuhnya masih menunggu peraturan pelaksana lebih lanjut.

Oleh karena itu kegiatan-kegiatan pengelolaan dan pemanfaatan hasil pertanian dan perkebunan masyarakat hukum adat Desa Niowula yang berada dalam areal Taman Nasional Kelimutu, dilakukan dengan cara kemitraan (kerjasama) antara masyarakat setempat dengan Balai Taman Nasional Kelimutu.

\section{PENUTUP}

KeberadaanmasyarakatadatdiIndonesia

telahmunculjauhsebelummasakemerdekaan ataubahkan telahada pada masa kejayaan 
kerajaan nusantara. Keberadaan masyarakatadatberikutdengan warisantanah adatnyabaik secara individual maupun secara komunal telah berlangsung lama. Sejarah mencatat bahwa masyarakat adat dan hukum adatnya sudah ada sejak tahun 1747 dengan istilah dalam Bahasa Belanda "zeijn wetten en gewoonten/undang-undang serta kebiasaan mereka; tahun 1804 dengan istilah inlandse of godsdiengstige wetten/undangundang pribumi atau agama; tahun 1825 dengan istilah godsdiengstige wetten of de zeden en oude herkomsten/undang-undang agama atau peraturan tata susila dan kebiasaan yang telah turun temurun; tahun 1848 dengan istilah godsdiengstige wetten, volkssinstelling en gebruiken/ undang-undang agama, peraturan lembaga dan kebiasaan rakyat, dan lain-lain. ${ }^{11}$

UU Nomor 5 Tahun 1960 tentang Pokok - Pokok Agraria yang menyebutkan bahwa hak - hak adat yang mencakup tanah, air danudara diakui sejauh tidak bertentangan dengan kepentingan nasional. Namun UU Nomor 41 Tahun 1999 jo UU Nomor 19 Tauhun 2004 tentang Penetapan Peraturan Pemerintah Pengganti Undang-undang Nomor 1 Tahun 2004 Tentang Perubahan atas Undang-undang Nomor 41 Tahun 1999 Tentang Kehutanan menjadi Undang-undang. Pada Undangundang Kehutanan dikenal adanya asas pegelolaan hutan yang meliputi prinsip hak menguasai negara, kesejahteraan masyarakat, keadilan, demokratis, transparan, terpadu dan berkelanjutan.

UU Nomor 39 Tahun 1999 Tentang HAM, khususnya konsiderans butir b disebutkan bahwa hak asasi manusia adalah hak dasar yang secara kodrati,bersifat universal dan langgeng yang melekat pada diri manusia, sehingga harus dilindungi, dihormati, dipertahankan, dan tidak boleh diabaikan, dikurangi atau dirampas oleh siapapun. Pasal 36 ayat 1 dan 2 tentang hak setiap orang untuk mempunyai hak milik dan jaminan tidak adanya perampasan secara sewenang-wenang atas hak miliknya dan Pasal 37 ayat 1 tentang persyaratan jika atas pencabutan hak milik yang demi kepentingan umum harus ada pemberian ganti rugi.

Ketentuan Pasal 6 ayat 1 dan 2 Undang-undang HAM disebutkan bahwa dalam rangka penegakan hak asasi manusia, perbedaan, dan kebutuhan dalam masyarakat adat harus diperhatikan dan dilindungi oleh hukum, masyarakat dan pemerintah. Identitas

\footnotetext{
${ }^{11}$ Sukirno, 2018, Politik Hukum Pengakuan Hak Ulayat, Prenamedia Group, Jakarta: hlm. 17.
} 


\section{Perlindungan Hukum Terhadap Hak Pengelolaan Dan Pemanfaatan Atas Tanah Hak Adat Milik Niowula Yang Berada Dalam Area Taman Nasional Kelimutu - Johanes Pande, Christiana Sri Murni \& Bernadus B. Kelen}

budaya masyarakat adat termasuk hak atas tanah ulayat dilindungi, selaras dengan perkembangan zaman.

Pasal 6 Undang-undang HAM sesungguhnya menegaskan keharusan bagi masyarakat dan pemerintah untuk menghargai kemajemukan identitas dan nilai-nilai budaya yang berlaku dalam komunitas adat. Penyangkalam terhadap kemajemukan identitas dan nilai-nilai budaya tersebut merupakan suatu bentuk tindakan pelanggaran hak asasi manusia, apalagi jika pengingkaran tersebut disertai dengan tindakan-tindakan pelecehan, kekerasan atau pemaksaan, maka dapat dikategorikan sebagai kejahatan serius atau berat.

Selain itu ketentuan dalam Pasal 5 UU HAM, juga menegaskan bahwa setiap orang termasuk kelompok masyarakat yang rentan berhak memperoleh perlakuan dan perlindungan lebih berkenaan dengan kekhususannya. Dalam rangka penegakan HAM, perbedaan dan kebutuhan dalam masyarakat adatpun harus diperhatikan dan dilindungi, termasuk Identitas budaya masyarakat adat, hak ulayatnyajuga mendapat perlindungan hukum dan jaminan kepastian dan keadilan.

Sejak berlakunya UUPA, hak masyarakat adat terabaikan karena UUPA tidak diimplementasikan sebagaimana mestinya, dimana keberadaan masyarakat adat dan hak ulayat kurang mendapat perhatian dan secara berangsur-angsur diperlemah melalui UUPA yang tidak secara jelas menetapkan pengaturan yang berkaitan dengan hak ulayat, hal inidapat dicermati dalam Pasal 3,5 dan 6 UUPA. Oleh karena itu maka Ketetapan MPR Nomor IX/MPR/2001 menetapkan untuk melakukan Pembaharuan Agraria dan Pengelolaam SDA. Dalam ketetapan MPR ini pada dasarnya mengemukakan beberapa hal penting diantara sebagaimana tertuang dalam konsideransnya butir c, d, e dan f mengemukakan bahwa, ternyata pengelolaan sumber daya agraria/sumber daya alam lingkungan selama ini telah menimbulkan penurunan kualitas, ketimpangan struktur penguasaan, pemilikan, penggunaan dan pemanfaatannya serta menimbulkan berbagai konflik. Selain itu peraturan perundang-undangan yang berkaitan sumber daya agraria/sumber daya alam saling tumpang tindih dan bertentangan satu sama lainnya. Untuk itu diperlukan adanya perubahan sistim pengelolaan sumber daya agraria/sumber daya alam yang lebih adil, berkelanjutan,dapat terkoordinasi, terpadu, dapat menampung dinamika, aspirasi dan peran serta masyarakat, serta dapat menyelesaikan konflik. Hal ini kemudian ditegaskan dalam 
Pasal 4 huruf j yang menegaskan bahwa "Pembaharuan agraria dan pengelolaan sumber daya alam harus dilaksanakan sesuai dengan prinsip-prinsip mengakui, menghormati, dan melindungi hak masyarakat hukum adat dan keragaman budaya bangsa atas sumber daya agraria/sumber daya alam".

Lebih lanjut dalam Pasal 32 Ketetapan MPR ini menekankan pengakuan dan penghormatan hak masyarakat adat yang disebutkan dengan kalimat, "Setiap orang berhak mempunyai hak milik pribadi dan hak tersebut tidak boleh diambil dengan sewenang-wenang”.Ketetapan MPR Nomor IX/MPR/2001 ini menginginkan adanya suatu UU yang mengatur tentang agraria dan pengelolaan sumber daya alam yang mampu sebagai payung yang bersifat "lex generalist" dari seluruh peraturan perundangundangan lainnya "lex specialist" yang bersifat sektoral yang mampu mengatur tentang aspek-aspek:

1. Pengaturan, penghormatan dan perlindungan eksistensi masyarakat adat beserta hak-hak tradisionalnya (hak ulayat atau dengan nama lain yang serupa dengan ini) dari perspektif hak asasi manusia, ekonomis, sosial dan yuridis.

2. Penjabaran norma yang jelas, terang, tegas dan mengedepankan filosofis bahwa penggunaan bumi, air, kekayaan alam yang terkandung didalamnya dan ruang angkasa dipergunakan untuk sebesar-besarnya kemakmuran rakyat; dan

3. Manifestasi, implementasi dan orientasi ditujukan kepada dimensi pencapaian keadilan sosial bagi seluruh rakyat Indonesia, pelestarian lingkungan, efektif, efisiensi dan pengelolaan SDA yang terus menerus dan berkelanjutan.

Peraturan Menteri Agraria dan Tata Ruang/Kepala Badan Pertanahan Nasional Nomor 9 Tahun 2015 mengatur tentang Tata Cara Penetepan Hak Komunal atas Tanah Masyarakat Adat dan Masyarakat yang berada dalam kawasan tertentu. Peraturan ini lahir dengan dasar pertimbangan untuk mewujudkan cita-cita luhur Bangsa Indonesia dalam pengelolaan sumber daya alam yang adil, berkelanjutan, sehingga perlu dilakukan pengkajian ulang terhadap Peraturan Perundang-undangan yang berkaitan dengan sumber daya alam. Selain itu bahwa hak-hak masyarakat yang menguasai tanah dalam jangka waktu yang cukup lama dan merupakan tempat hidup dan mencari kehidupan perlu diberikan perlindungan dalam rangka mewujudkan kemakmuran rakyat. 


\section{Perlindungan Hukum Terhadap Hak Pengelolaan Dan Pemanfaatan Atas Tanah Hak Adat Milik Niowula Yang Berada Dalam Area Taman Nasional Kelimutu - Johanes Pande, Christiana Sri Murni \& Bernadus B. Kelen}

Kelompok masyarakat adat dan kelompok masyarakat dalam kawasan tertentu dapat diberi hak atas tanah setelah melalui proses yang ditentukan dan diberikan dalam bentuk hak komunal. Pemberian hak komunal berupa penetapan oleh Bupati/wali kota untuk masyarakat adat atau masyarakat yang berada dalam kawasan tertentu dalam hal tanah terletak pada 1) kabupaten atau kota atau oleh gubernur, untuk masyarakat adat atau masyarakat yang berada dalam kawasan tertentu dalam hal tanah terletak dalam lintas kabupaten atau kota. Penetapan tersebut disampaikan kepada Kepala Kantor Pertanahan atau Kepala Kantor Wilayah Badan Pertanahan Nasional untuk didaftarkan hakatas tanahanya pada Kantor Pertanahan setempat. Sertifikat hak atas tanah yang didaftarkan tersebut dapat diberikan atas nama anggota masyarakat adat atau masyarakat yang berada dalam kawasan tersebut, pengurus koperasi atau unit bagian dari desa, atau kepala adat/ketua/pimpinan kelompok masyarakat lainnya. Hak komunal yang diberikan kepada masyarakat hukum adat yang telah didaftarkan, penggunaan dan pemanfaatan tanahnya dapat dikerjasamakan dengan pihak ketiga sesuai ketentuan dalam peraturan perundang-undangan dan kesepakatan para pihak. 


\section{DAFTAR PUSTAKA}

\section{Buku-buku}

Lilik Mulyadi, 2017, eksistensi, dinamika dan perlindungan hokum terhadap hak atas tanah ulayat masyarakat adat di Indonesia, PT. Alumni, Bandung.

Otje Salman Soemadiningrat, 2002, Rekonseptualisasi Hukum Adat Kontemporer, PT. Alumni, Bandung.

Suharso dan Anna Retnoningsih, 2014, Kamus Besar Bahasa Indonesia, Widya Karya, Semarang.

Sukirno, 2018, Politik Hukum Pengakuan Hak Ulayat, Prenadamedia, Jakarta.

Wilfridus Josephus Sabarija Poerwadarminta, 2008,Badan Pengembangan dan Pembinaan Bahasa, Kamus Besar Bahasa Indonesia edisi keempat tahun, Balai Pustaka, Jakarta.

\section{Undang-undang dan Peraturan}

Undang-undang Dasar Negara Kesatuan Republik Indonesia Tahun 1945

Undang-undang Nomor 5 Tahun 1990 Tentang Konservasi Sumber Daya Alam Hayati dan Ekosistemnya.

Undang-undang Nomor 39 Tahun 1999 Tentang Hak Asasi Manusia

Undang-undang Nomor 41 Tahun 1999 Tentang Kehutanan

Peraturan Pemerintah Nomor 6 Tahun 1999 Tentang Penguasaan Hutan dan Pemungutan Hasil Hutan Produksi

Peraturan Presiden Nomor 88 Tahun 2017 Tentang Penyelesaian Penguasaan Tanah Dalam Kawasan Hutan

Peraturan Menteri Kehutanan Nomor P.56/Menhut-II/2006 Tentang Pedoman Zonasi Taman Nasional.

Peraturan Menteri Agrari/Kepala Badan Pertanahan Nasional Nomor 5 Tahun 1999 Tentang Pedoman Penyelesaian Masalah Hak Ulayat Masyarakat Hukum Adat

Peraturan Kepala Badan Pertanahan Nasional Nomor 1 Tahun 2011

\section{Jurnal}

Nanang Fattah, 2004, http://eprints. uny. ac. id/7900/3/bab2\%20-\%2006101244019. 